DOI 10.37882/2500-3682.2020.12.28

\title{
САМОСОЗНАНИЕ КАК УНИКАЛЬНОЕ СВОЙСТВО ЧЕЛОВЕЧЕСКОЙ СУЩНОСТИ
}

\section{SELF-AWARENESS AS A UNIQUE PROPERTY OF A HUMAN ENTITY}

\section{T. Nikolaeva}

Summary: In this article, the author considers self-awareness as a unique property of the human essence. The author reveals the main problems that can be aimed at scientific research on the further study of the process of self-awareness in human nature. The author analyzed the ontogenetic features of the formation of self-consciousness as the basis of its uniqueness. Some world sources (to William James) and the concept of the development of human self-awareness (Z. Freud, C.G. Jung, E. Fromm, A. Adler, K. Horney, E. Burns, E. Erickson) are analyzed. The author emphasizes that the formation of self-awareness is determined by the age characteristics of the individual, which go through several stages of their development.

Keywords: self-consciousness, human essence, features of selfconsciousness, development of self-consciousness, philosophy.

\author{
Николаева Татьяна Анатольевна \\ к.ф.н., ФГБОУ ВО «Тихоокеанский государственный \\ университет» (2. Хабаровск) \\ 004012@pnu.edu.ru
}

Аннотация: В данной статье автор рассматривает самосознание как уникальное свойство человеческой сущности. Автором раскрыты основные проблемы, на которые могут быть нацелены научные исследования по вопросам дальнейшего изучения процесса самосознания в природе человека. Автором проанализированы онтогенетические особенности становления самосознания как основы ее уникальности. Проанализированы некоторые мировые источники (Уильяму Джемсу) и концепции развития самосознания человека (3. Фрейд, К.Г. Юнг, Э. Фромм, А. Адлер, К. Хорни, Э. Бёрнс, Э. Эриксон). Автор подчеркивает, что формирование самосознания определяется возрастными особенностями индивида, которые проходят несколько стадий своего развития.

Ключевые слова: самосознание, человеческая сущность, особенности самосознания, развитие самосознания, философия.

ходят свое развитие на основе оценочного отношения ближайшего окружения и определенной деятельности в рамках познания себя на определенных этапах онтогенеза и как следствие данное понятие можно охарактеризовать как уникальное свойство человеческой сущности. Рассмотрим его становление через призму онтогенеза.

Формирование образов самосознания всегда определяется как результат социального взаимодействия человека и окружения. Изначальные образы возникают как определенные совместные образования, формирующие представления человека о себе, как о представителе социума, отличного от других. [1, с. 113].

Самосознание как уникальное свойство человеческой природы формируется на основе прохождения определенных этапов развития, которые напрямую связаны с определенными условиями психического развития человека. Эти стадии можно условно выделить как: от рождения до года, от трех до 7 лет, от 7 до 12, от 12 до 14 и от 14 до 18 лет. Данные возрастные этапы последовательно сменяют друг друга и в последствие, могут изменять границы возраста в зависимости от индивидуальных факторов и факторов окружающей среды [4, с. 24].

Анализируя мировые источники, относительно развития самосознания, можно сделать вывод, что основной вклад в разработку проблемы внесли фрейдисты и пред- 
ставители гуманитарной психологии. Так, рассматривая психоаналитическую концепцию 3. Фрейда, мы видим единство сознания и самосознания, которые являются, с точки зрения учёного, одной определенной сферой жизни. Данная концепция раскрывает предпосылки развития самосознания, основанные на двух предпосылках: генетической и инстинктивной. Являясь фундаментом и, играя важную роль в формировании личности, генетическая предпосылка основана на тех переживаниях, которые затрагивают раннее детство. Однако главным фактором, по мнению 3. Фрейда, который определяет развитие человека, следует считать инстинкт [4]. Ярким представителем фрейдизма считается К.Г. Юнг, чьи научные работы, так же как и 3. Фрейда, относительно представлений о самосознании, имеют большое значение для мировой науки. Исследование личностного «Я», которое К.Г. Юнг рассматривал как бессознательное и первичное образование, позволило увидеть в «Я» стремление к целостности и единству. Индивидуальное бессознательное, по мнению ученого, является также и коллективным бессознательным, поскольку является одинаковым у многих людей, объединяя, таким образом, все человечество в целом. Также широко известна теория К.Г. Юнга самости, суть которой единство сознательного и бессознательного; они могут как противостоять друг другу, так и дополнять друг друга, образуя единое целое, которое учёный называет самостью. Противоположную точку зрения на данную проблему высказывают представители неофрейдизма, чьи идеи имеют большое значение для общественной жизни, этики и культуры человечества (Э. Фромм, А. Адлер, К. Хорни, Э. Бёрнс, Э. Эриксон и др.). Неофрейдисты отвергали идею о ведущей роли инстинктов в развитии личности, подчеркивая большое влияние окружающей среды. Значимой для мировой психологии является открытие Э. Фромма относительно единства личности с внешним миром. Так, по Э. Фромму, в период детства основная роль принадлежит семье, в дальнейшем решающую роль в развитии личности играет общество, которому подчинена вся экономическая и политическая деятельность. Другой яркий представитель неофрейдизм А. Адлер, так же, как и Э. Фромм, подчеркивает влияние социального окружения на формировании структуры личности, где главную роль в детстве играет семья и окружающие люди. Самым важным в формировании личности учёный считает стиль жизни, который определяет поведение человека, поскольку является одним из врожденных бессознательных чувств, составляющих структуру «Образа Я», где важное место занимает «Я творческое», которое и формирует жизненный стиль личности. «Творческое Я» это тот фермент, который влияет на факты окружающей действительности, трансформируя эти факты в саму личность. Однако, А. Адлер подчеркивал, что для достижения цели жизни необходимо преодоление личностных комплексов и стремление к превосходству. Влиятельным представителем неофрейдизма также считается
Э. Эриксон. Его теория, относительно развития личности, становление «Я» основана на концепции кризиса подросткового возраста [2].

Как говорилось ранее, в процессе своего развития, самосознание человека проходит несколько стадий. Развитие самосознания начинается на самых ранних стадиях онтогенеза в процессе отделения ребенка от мира предметов и других людей. Вначале оно не отличается от других. Он также не может отличить свои движения от тех, которые принадлежат ему, но взрослый выполняет их в процессе заботы о ребенке. Первые игры ребенка сначала с частями его тела (ручки, ножки), а затем с объектами внешнего мира свидетельствуют о первичной дифференциации его активной и пассивной роли в двигательной активности. В процессе двигательной активности, при манипуляциях с объектами и в процессе взаимоотношений с взрослым постепенно реализуется физическое «Я» ребенка, отдельные органы чувств и части тела.

Необходимым условием развития самосознания является появление у ребенка способности самостоятельно передвигаться в пространстве. Этот факт порождает новые формы отношений со взрослым, которые открывают новые пути и источники познания собственных возможностей, расширяют границы познания себя и качества самостоятельного субъекта [2, с. 25].

Третий год жизни - это период интенсивного умственного развития. Если раньше ребенок не думал о себе отдельно от привычных условий, ощущал чувство слияния с другими, называл себя по имени, говорил о себе в третьем лице, то к 3 годам «это слияние ребенка с другими вдруг исчезает, и личность вступает в период, когда необходимость утвердить и завоевать свою самостоятельность приводит ребенка к ряду конфликтов. Прежде всего, это противостояние самого себя другим, часто весьма негативное. В результате, ребенок невольно оскорбляет окружающих его людей просто потому, что хочет испытать свою самостоятельность, почувствовать свое собственное существование. В этих случаях единственной формой самоутверждения является сама победа. Подавленный более сильной волей другого человека или потребностью, ребенок болезненно переживает снижение своей значимости [3, с. 56]. Это период, когда в психическом мире личности формируются нравственные системы и комплексы, которые в дальнейшем могут перейти в твердые черты личности. На этом этапе характер взаимоотношений между ребенком и взрослым приобретает решающее значение. Поскольку ребенок еще не обладает достаточными знаниями о себе и о взаимоотношениях с самим собой, он спонтанно принимает отношение близкого взрослого (мать, отец и т.д.) к самому себе[8].

Развитие самосознания после 3 лет идет в направле- 
нии возрастающего самоутверждения личности ребенка, происходит дальнейшее накопление его познавательного, аффективного и волевого опыта, что выражается в возрастающей адекватности самооценки [4, с. 56].

В период от 7 до 12 лет процесс развития самосознания происходит плавно, без заметных скачков и ограничений. В это время накапливаются умственные резервы, которые приведут самосознание к его важнейшей генетической форме в подростковом возрасте.

Самосознание подростка характеризуется значительными, выраженными изменениями. Это обстоятельство часто дает основание полагать, что самосознание впервые появляется у подростка. Собственно, оно является очередным этапом самосознания, хотя и исключительно значимым в психическом развитии личности, которое формируется только на основе когнитивного, эмоционального и регулятивного опыта самосознания, накопленного в предыдущие периоды и ставшего потенциальным резервом для его дальнейшего развития $[1$, с. 45]. Подростковый возраст - это второй критический период (после кризиса 3-х лет) психического развития ребенка, необходимый для генезиса самосознания как части человеческой сущности. Мы специально не останавливаемся на этапах, когда кризисы 1 года и 7 лет менее важны для генезиса самосознания. Для этих периодов главное - это познание ребёнком своего внешнего существования, дальнейшее освоение отношений с реальным и социальным миром, а развитие самосознания в это время происходит плавно, без резких скачков.

K 12 годам внимание ребенка вновь начинает привлекать его личность. Однако новый кризис развивается в направлении, противоположном раннему. Он также начинается с противодействия, но направлен не столько на самих людей, сколько на привычки, установки и проявления, связанные с ними в более широком контексте нравственных норм и позиций. Если трехлетний ребенок стремится подражать взрослому, то подросток, напротив, хочет отличаться от него, противопоставлять себя, быть самостоятельным. Если трехлетний ребенок заявляет о своей самостоятельности при осуществлении каких-либо практических действий, то стремление под- ростков к самостоятельности выражается в возникновении осознания своей причастности у взрослых, хотя это осознание часто противоречит реальным способностям подростка [6, с. 58].

Подростковый этап генезиса самосознания как уникальной характеристики особенно значим для развития личности, так как на этом этапе он переходит в качественно новую стадию, которая знаменует собой начало его зрелости. Взаимосвязь между генезисом самосознания и общим психологическим развитием личности становится иной. Теперь самосознание не только отражает особенности формирования личности, но и существенно влияет на весь процесс ее дальнейшего развития. Поэтому на юношеской стадии самосознания будут определяться не только пути его дальнейшего развития, но и в большей степени психического развития личности в целом $[7$, с. 66].

Таким образом, при переходе от одной стадии к другой происходит последовательное усложнение, расширение сферы деятельности и повышение роли самосознания в процессе развития человека и его сущности.

Формирование самосознания проходит несколько стадий и определяется ведущими этапами развития ребенка. В рамках первоначального периода ребенок учится взаимодействовать со своим телом и манипулировать предметами. Развитие самосознания в более поздних периодах характеризуется наличием определенного стиля межличностных взаимоотношений и повышенный интерес подростков к собственной личности. Самосознание представляет собой уникальную характеристику личности, которая определяет отношение человека к себе и окружающей его действительности. Самосознание человека формируется при непосредственном взаимодействии человека с ближайшим окружением и как следствие, формирование определенного опыта в данной области. Самосознание, имеющее отражательную природу, направленную на личность, ее внутренний мир, есть процесс познания самого себя, характеризующийся созданием своего продукта - «Я - концепция», где личность выступает в качестве и субъекта, и объекта познания. Думается, что основной функцией самосознания является саморегуляция поведения.

\section{ЛИТЕРАТУРА}

1. Божович Л.И. Личность и её формирование в детском возрасте. Психологическое исследование. / Л. И. Божович. - М.: Просвещение, 2018. -223 с.

2. Декарт Р. Первоначала философии // Сочинения: в 2 т. / Р. Декарт. Т. 1. М.: Мысль, 1989. С. 297—422.

3. Кант И. Критика чистого разума / Пер. с нем. Н. Лосского сверен и отредактирован Ц.Г. Арзаканяном и М.И. Иткиным; Примеч. Ц.Г. Арзаканяна. М.: Мысль, 2017. 591 с.

4. Карпов, А.В. Психология рефлексивных механизмов деятельности / А.В. Карпов. - М.: Институт психологии РАН, 2016. 424 с.

5. Лазарев Ф.В., Лебедев С.А. Философская рефлексия: сущность, типы, формы // Вопросы философии. 2016. № 6. С. 15 - 28.

6. Лисина М.И. Проблемы онтогенеза общения / НИИ общей и педагогической психологии АПН СССР. - М.: Педагогика, 2016. - 214 с. 
7. Новая философская энциклопедия. В 4 томах. М.: Мысль, 2015. Т. 1. 744 с., Т. 2. 634 с., Т. 3. 692 с., Т. 4.736 с.

8. Сасина Л.А. Рефлексия как инструмент развития самосознания студенческой молодежи // Актуальные научные исследования в современном мире // Изд.: Общественная организация «Институт социальной трансформации». Переяслав-Хмельницкий, 2016. № 10 (18). С. 131 - 136.

9. Х Хелл Л. Теории личности (основные положения, исследования и применение) / Л. Хьелл, Д. Зиглер. - СПб.: Питер Пресс, 2017. - 608с.

(c) Николаева Татьяна Анатольевна (004012@pnu.edu.ru)

Журнал «Современная наука: актуальные проблемы теории и практики»

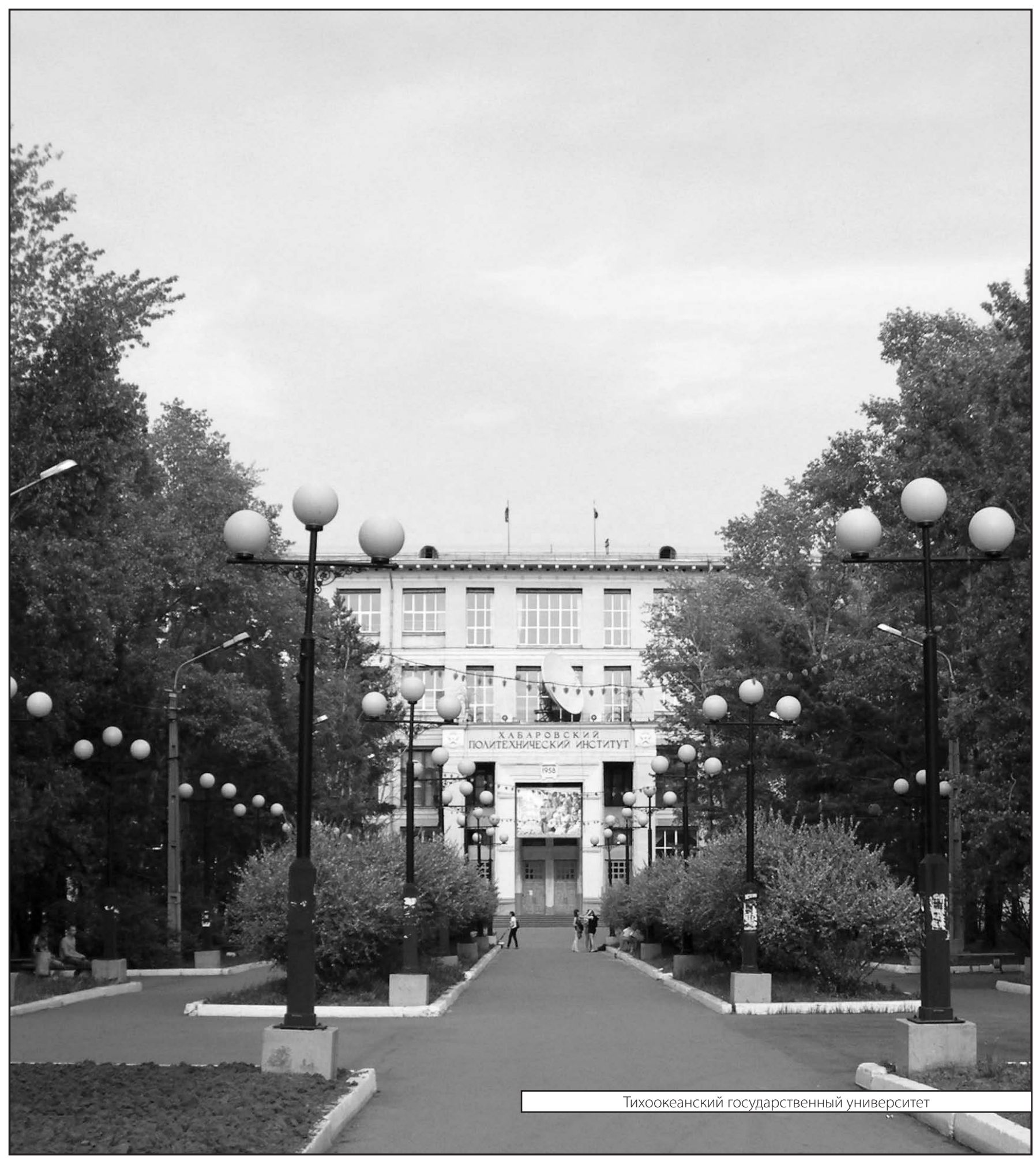

